\title{
PERGUMULAN KULTUR DAN STRUKTUR DALAM MANAJEMEN ZAKAT DI POHUWATO GORONTALO
}

\author{
Ahmad Faisal ${ }^{1}$ \\ Dosen Fakultas Syariah \\ Institut Agama Islam Negeri (IAIN) Sultan Amai Gorontalo \\ Jl. Sultan Amai, Pone, Limboto, Kota Gorontalo, Indonesia \\ Email: ${ }^{1}$ ahmadfaisal@iaingorontalo.ac.id
}

\begin{abstract}
This article analyses the management of zakat by local governments. This study is focused on Pohuwato Regency in Gorontalo Province. As a relatively new religious idea, the idea of strengthening zakat management through the Regulations of the Regent is responded variedly by Muslim communities in this area. In general, they show responsive views. They are still categorized into two trends, namely, cultural and structural. This categorization is especially prominent when debating government involvement, community trust, socialization facts, and relevant distribution patterns. Even so, the tendency and categorization seemed to be significantly influenced by people's perceptions and knowledge of the whole discourse that accompanied the idea. Muslim communities generally agree with the Regents' Regulations on zakat, even though they do not know of its existence. Community turmoil only lies in the management of zakat.
\end{abstract}

Keywords: Culture, Structure, Zakat Management.

\begin{abstract}
Abstrak
Artikel ini menganalisa manajemen zakat oleh pemerintah daerah. Studi ini difokuskan di Kabupaten Pohuwato, Provinsi Gorontalo. Sebagai gagasan keagamaan yang relative baru, gagasan penguatan manajemen zakat melalui Peraturan Bupati ditanggapi secara variatif oleh masyarakat Muslim di daerah ini. Secara umum, mereka menunjukkan pandangan yang responsive, tetap saja terkategorisasi dalam dua kecendrungan, yakni kultural dan structural. Kategorisasi tersebut terutama menonjol ketika memperdebatkan keterlibatan pemerintah, kepercayaan masyarakat, fakta sosialisasi, dan pola distribusi yang relevan. Pun demikian, kecendrungan dan kategorisasi itu tampak sangat dipengaruhi oleh persepsi dan pengetahuan masyarakat terhadap keseluruhan wacana yang menyertai gagasan tersebut. Masyarakat muslim umumnya sepakat dengan Peraturan Bupati tentang zakat, meskipun mereka tidak mengetahui keberadaannya. Kegalauan masyarakat hanya terletak pada sistem pengelolaan zakat.
\end{abstract}

Kata Kunci: Kultur, Struktur, Manajemen Zakat. 


\section{PENDAHULUAN}

Secara normatif, zakat merupakan salah satu rukun Islam. Ibadah ini mengandung makna simbolik keagamaan yang berdimensi ganda, yakni secara vertikal dengan Tuhan dan secara horizontal dengan manusia (umat). Oleh karena itu, setiap Muslim yang menunaikannya akan memperoleh dua kesalehan, yaitu "kesalehan personal" dan "kesalehan sosial."

Selain itu, dalam dimensinya yang paling dalam, zakat memiliki peran perubahan sosial dalam masyarakat. Dana umat yang terkumpul dari zakat dapat digunakan untuk membiayai program-program pemberdayaan dan perubahan sosial yang vital. Seperti pengembangan masyarakat miskin, peningkatan pelayanan kesehatan, pendidikan, dan pelayanan-pelayanan publik lainnya. Menurut Yusuf al-Qardhawi, zakat merupakan ibadah maliyah ijtimaiyah yang memiliki posisi yang sangat penting, strategis dan menentukan, baik dari sisi ajaran maupun sisi pembangunan dan kesejahteraan umat. ${ }^{1}$

Secara normatif ${ }^{2}$ maupun historis, ${ }^{3}$ Islam secara tegas memposisikan pemerintah sebagai penanggung jawab untuk mempelopori dan mensukseskan pengelolaan zakat. Karena itulah harus ada lembaga amil zakat yang ditugasi oleh pemerintah untuk mengelola, mendistribusikan dan melaporkannya. Di zaman Rasulullah, zakat berhasil dikelola dengan baik, karena didukung oleh kesadaran umat. Kekuatan ayat Alquran dan ucapan Nabi, berhasil menggiring kesadaran orang-orang kaya ketika itu untuk mengeluarkan zakat, sehingga mereka secara sukarela mau menunaikan zakat, tanpa paksaan sedikitpun. ${ }^{4}$

\footnotetext{
${ }^{1}$ Yusuf al-Qardhawi, Fiqh Zakat, Dirasah Muqaranah li Ahkamiha wa Falsafatiha fiy Dhau' al-Qur'an wa al-Sunnah (Beirut: Muassasahal-Risalah, 1997), h. 2.

${ }^{2} \mathrm{Di}$ antara ayat yang sering diuktip sebagai rujukan dalam konteks kewajiban zakat adalah QS. Al-Taubah (9) :103 dan QS. Al-Baqarah (2): 267.

${ }^{3}$ Menurut al-Mawardi, negara/pemerintah memang dibentuk untuk melanjutkan tugastugas kenabian dalam mengurusi masalah keagamaan dan keduniawian. Lihat Abu al-Hasan alMawardi, al-Ahkam al-Sulthaniyat wa al-Wilayah al-Diniyat (Beirut: Dar al-Fikr, t.th.), h. 5; Mustafa Edwin Nasution, Pengenalan Eksklusif Ekonomi Islam (Jakarta: Kencana, 2006), h. 214.

${ }^{4}$ Wahbah al-Zuhaily, "Dirasah Muqaranah fi Zakat al-Mal," diterjemahkan oleh Agus Efendi dan Bahruddin Fannany dengan judul Zakat: Kajian Berbagai Mazhab(Bandung: Remaja Rosdakarya, 2000), h. 12.
} 
Praktik semacam ini juga berlangsung pada masa-masa selanjutnya. Pada masa Abu Bakar al-Shiddiq, warga yang enggan membayar zakat bahkan diperangi. ${ }^{5}$ Beliau merasa wajib untuk mengefektifkan penghimpunan zakat. Demikian pula halnya pada masa Umar dan khalifah-khalifah selanjutnya. Bahkan pada masa Umar, telah dirintis manajemen pendistribusian dengan pertimbangan skala prioritas. Sejarah mencatat misalnya, dalam pendistribusian zakat, Umar bin Khattab tidak lagi memberikan bagian zakat kepada muallaf (Muslim pemula) karena pertimbangan tertentu. ${ }^{6}$

Di Indonesia, secara yuridis formal, pemerintah telah menerbitkan banyak regulasi tentang zakat, di antaranya: Undang-Undang Nomor 38 Tahun 1999 tentang Zakat yang telah diperbaharui dengan Undang-Undang Nomor 23 Tahun 2011 tentang Pengelolaan Zakat. Peraturan Pemerintah No. 14 Tahun 2014 tentang Pelaksanaan UU No. 23 Tahun 2011; Instruksi Presiden No. 3 Tahun 2014 tentang Optimalisasi Pengumpulan Zakat di Kementerian/Lembaga. Sekretariat Jenderal Lembaga Negara, Sekretariat Jenderal Komisi Negara, Pemerintah Daerah, Badan Usaha Milik Negara, Badan Usaha Milik Daerah melalui Badan Amil Zakat Nasional. Keputusan Menteri Agama No. 118 Tahun 2014 tentang Pembentukan Baznas Provinsi dan sejumlah peraturan turunan lainnya. Dengan dasar legalitas yang ada, mestinya spirit dan aksi pemberdayaan terhadap umat semakin membaik. Tetapi dalam implementasinya di lapangan tampaknya masih abu-abu, belum menunjukkan hasil yang diharapkan.

Beberapa daerah seperti DKI Jakarta dan Kalimantan Timur, pengelolaan zakatnya sudah berjalan dengan baik, dengan hasil yang juga menggembirakan. Hal itu dapat terwujud dengan diterbitkannya Perda Zakat, sebagai payung hukum dan petunjuk teknis lainnya terhadap hal-hal yang belum diatur dalam UU Zakat. Dengan kesadaran yang sama, maka pada tahun 2017, Kabupaten Pohuwato telah

\footnotetext{
${ }^{5}$ Ahmad Munif, Suratmaputra, Filsafat Hukum Islam (Jakarta: Pustaka Firdaus, 2002), h. 104;Hassan Saleh, Kajian Fikih Nabawi dan Fikih Kontemporer (Jakarta: Raja Grafindo Persada, 2008), h. 37.

${ }^{6}$ Iskandar Usman, Istihsan dan Pembaharuan Hukum Islam (Jakarta: Raja Grafindo, 1994), h. 184; Muh. Nur Ichwan, Meretas Kesarjanaan Kritis Alquran (Jakarta: Teraju, 2003), h. 146; Faisal, "Sejarah Pengelolaan Zakat di Dunia Muslim dan Indonesia" dalam Jurnal Analisis Vol. XI, Nomor 2 Desember 2011, h. 248.
} 
menetapkan Keputusan Bupati Pohuwato Nomor 434 Tahun 2017 sebagai payung hukum pengelolaan zakat di daerah ini.

Masalahnya kemudian, setelah dua tahun pemberlakuan Peraturan Bupati, manajemen pengelolaan zakat di daerah ini masih menunjukkan perkembangan yang kurang menggembirakan. Selain kebijakan pemotongan gaji terhadap para Aparatur Sipil Negara (ASN) di lingkungan pemerintahan kabupaten, nyaris tidak ada implementasi manajemen yang tampak di lapangan, baik itu berupa perencanaan, tindak lanjut, pengawasan maupun evaluasi. Dalam kondisi seperti itu, secara sederhana dapat dinyatakan bahwa manajemen zakat masih dilakukan secara konvensional, atau dalam bahasa lain masih menerapkan manajemen kultural.

\section{METODOLOGI}

Masalah pokok penelitian ini adalah bagaimana pergumulan kultur dan struktur dalam pengelolaan zakat sejak terbitnya Peraturan Bupati tersebut? Penelitian ini adalah penelitian kualitatif yang berbentuk descriptive research atau taxonomic research. ${ }^{7}$ Ia bermaksud untuk mengklarifikasi dan mengekplorasi penjelasan bagaimana pergumulan persepsi masyarakat Muslim terhadap upaya pelembagaan zakat melalui struktur atau penguatan manajemen dan regulasi zakat di Kabupaten Pohuwato tahun 2019. ${ }^{8}$

Studi ini pertama-tama mendasarkan diri pada hasil wawancara. Wawancara dilakukan secara tidak berstruktur (unstructured interview) tetapi berfokus (focused interview). Responden dibedakan atas dua kategori, yakni responden kategori muzakki dan kategori mustahiq. Seleksi individu dilakukan dengan cara purposive stratified.

${ }^{7}$ Penelitian deskriptif (descriptive research) biasa juga disebut penelitian taksonomik (taxonomic research) adalah jenis penelitian yang bermaksud mengekplorasi dan mengklarifikasi suatu fenomena dengan jalan mendeskripsikan sejumlah variabel yang berkenaan dengan masalah dan unit yang diteliti. Jenis penelitian ini tidak mempersoalkan hubungan antar variabel, tidak dimaksudkan untuk mencari generalisasi yang menjelaskan variabel-variabel anteseden, dan karenanya tidak menggunakan dan tidak melakukan pengujian hipotesis. Lihat Sanafiah Faisal, Format-Format Penelitian Sosial: Dasar-Dasar dan Aplikasi (Jakarta: Raja Grafindo Persada, 2007), h. 20.

${ }^{8}$ Lihat Lexy J. Maleong, Metodologi Penelitian Kualitatif (Cet. 37, Bandung: Remaja Karya, 2017), h. 4-5. 
Selain wawancara, juga dilakukan sampling secara purposive sample (sampel bertujuan). ${ }^{9}$ Adapun penentuan proporsionalnya (to purfose), dilakukan dengan mempertimbangkan faktor domisili, usia, pekerjaan, pendidikan, jenis kelamin dan lain-lain. Untuk penelitian ini, telah dilakukan wawancara dan pembagian kuesioner kepada 1000 responden, terdiri dari 400 responden mewakili mustahiq, 400 responden kategori muzakki dari kalangan PNS, dan 200 responden kategori muzakki dari kalangan non-PNS.Untuk penelitian ini, pengumpulan data juga menggunakan penelusuran data sekunder. Di samping itu, digunakan pula metode observasi dengan cara non-participant.

\section{PEMBAHASAN}

\section{Pandangan Masyarakat terhadap Gagasan Pengelolaan Zakat}

Pada umumnya, umat Islam Kabupaten Pohuwato percaya dan mengakui bahwa zakat merupakan salah satu perintah agama. Akan tetapi, mengakui zakat sebagai salah satu perintah agama merupakan satu hal, sementara memahaminya secara benar adalah hal lain. Bahkan dalam konteks bagaimana zakat harus dipahami inilah, terletak persoalan yang sebenarnya. Ada sejumlah faktor yang mempengaruhi dan membentuk hasil pemahaman umat terhadap zakat, apalagi upaya pelembagaannya. Kecenderungan tingkat kepercayaan yang berbeda terhadap lembaga yang ada misalnya, dapat berujung pada pemahaman yang berbeda pula mengenai bagaimana seharusnya zakat dikelola. Karenanya, kendati umat Islam Kabupaten Pohuwato mengakui pentingnya pengelolaan zakat, pemahaman mereka tentang dengan cara dikelola, diwarnai perbedaan-perbedaan.

Sebagai gagasan yang penjelasannya dalam agama sudah jelas (ma'lum min al-din bi al-dharurat). ${ }^{10}$ Gagasan pengelolaan zakat sesungguhnya bukanlah persoalan yang perlu lagi diperdebatkan. Siapapun umat Islam, menyadari bahwa

${ }^{9}$ Prosedur penggunaan sampel dalam penelitian kualitatif dalam dibaca secara rinci dalam Lexy J. Moleong, Metodologi Penelitian Kualitatif, h. 223-225.

${ }^{10}$ Zakat secara harfiyah berarti pertumbuhan (al-nama'), suci (al-thaharah) dan berkah (al-barakah). Secara istilah, zakat adalah sebagian (kadar) harta yang memenuhi syarat minimal (nishab) dan rentang waktu satu tahun (haul) yang menjadi wajib untuk diberikan kepada mustahiq (penerima zakat).Abd al-Rahman al-Jaziry, Kitab al-Fiqh ala Madzahib alArba'ah, Juz I (Beirut: Dar al-Fikr, 1990), h. 590; Sayid Sabiq, Fiqh Sunnah, Juz I (Beirut: Dar alFikr, 1983), h. 276. 
bagi seorang Muslim, wajib atasnya untuk menunaikan zakat, karena ketentuannya sudah sedemikian eksplisit dalam ajaran agama. ${ }^{11}$

Bagi umat Islam Kabupaten Pohuwato, wacana pengelolaan zakat sudah pasti disambut dengan baik dengan sejumlah argumen-argumen yang mendasarinya. Oleh karena itu, bagian ini tidak diorientasikan untuk melacak bagaimana pandangan umat Islam Kabupaten Pohuwato terhadap wacana pengelolaan zakat an sich. Tetapi lebih diarahkan pada perdebatan dan responsnya terhadap gagasan pengelolaan zakat melalui Perbup yang telah ditetapkan.

Uraian berikut akan diorientasikan untuk memberi gambaran tentang pandangan dan respons masyarakat Muslim Kabupaten Pohuwato terhadap Peraturan Bupati dengan segala aspek yang terkait dengannya, misalnya klausul tentang pemotongan 2,5\% gaji bagi PNS setiap bulannya. Kecenderungan yang dikemukakan di sini lebih merupakan sketsa yang didasarkan pada kecenderungan-kecenderungan umum respons mereka. Tentu saja, sebuah sketsa barulah merupakan gambaran awal dan belum merupakan hasil final. Karena itu, pada sketsa dari kecenderungan pemikiran yang diuraikan di sini, sangat mungkin terjadi kesamaan, tumpang tindih, pertentangan ataupun kohesi di antara kecenderungan yang diformulasikan. Tetapi, bagaimanapun juga, kategorisasi ini dianggap bermanfaat untuk lebih mencermati pola-pola, corak dan arah pemikiran umat Islam terhadap gagasan penguatan manajemen dan regulasi zakat melalui Peraturan Bupati di daerah ini.

Masyarakat Muslim Kabupaten Pohuwato, pada dasarnya setuju dengan gagasan pengelolaan zakat. Akan tetapi, terhadap gagasan pengelolaan zakat secara formal melalui Perbup, maka tampaknya mereka terpola dalam beberapa kecenderungan.

Pertama, kecenderungan kontra-pesimis. Kecenderungan ini, didukung oleh 10,4\% responden. Ciri pokok yang mendasari pemikiran mereka adalah adanya anggapan bahwa selama ini tanpa Peraturan Bupati, zakat telah ditunaikan oleh masyarakat Muslim, sehingga tidak perlu diatur melalui Peraturan Bupati. 
Dalam kata-kata apologetik, terungkap bahwa "jangan-jangan suatu saat salat juga di perbupkan, karena perintah kewajibannya sama dalam agama."12

Besarnya penentangan terhadap campur tangan pemerintah dalam pengelolaan zakat, mendorong mereka memilih pendekatan "kulturalis". Pilihan pada pendekatan itu didasarkan pada asumsi bahwa pelaksanaan kewajiban agama biarlah menjadi pilihan kesadaran masing-masing orang. Tidak perlu pemerintah campur tangan dalam pengelolaannya. ${ }^{13}$ Dalam kata-kata yang juga tampak sinis, dikatakannya bahwa "lebih baik pemerintah fokus mengurusi tugasnya dalam pelayanan birokrasi, dan kalau ingin mensejahterakan masyarakat, sebaiknya jangan korupsi." ${ }^{14}$ Kutipan pernyataan terakhir inilah yang tampaknya menjadi kata kunci (key word) mengapa mereka pesimis dengan keterlibatan pemerintah dalam pengelolaan zakat. Artinya, penolakan mereka tampaknya tidak menggambarkan bahwa mereka tidak setuju secara substansial. Tetapi lebih disebabkan oleh rendahnya kepercayaan terhadap lembaga pengelola, apalagi jika dikelola pemerintah.

Dalam hal kepercayaan (trust), tampak bahwa mereka yang berada pada kecenderungan ini betul-betul sudah tidak punya harapan terhadap perbaikan kinerja pemerintah dalam pengelolaan keuangan. Dengan kata lain, tingkat kepercayaannya sudah berada di titik nadir. Dalam ungkapan yang sering mengemuka, mereka sangat pesimis bahkan curiga, sebab dengan dana yang pola pelaporannya kepada negara jelas, ternyata tetap dapat di mark-up, apalagi dana zakat yang tidak secara resmi akan diaudit oleh auditor negara. Ketika digambarkan bahwa dalam pengelolaan zakat nantinya juga akan melibatkan lembaga auditor, sekali lagi, lembaga auditor pun ikut menjadi sasaran kecurigaan. Karena itu, bagi mereka, biarlah zakat berjalan secara kultural seperti sekarang saja, tidak perlu ada Perda dan lembaga yang mengelolanya. Pengelolaannya cukup diserahkan kepada kesadaran masing-masing muzakki. Kelalaian dalam menjalankan kewajiban zakat, menurut mereka biarlah nanti

\footnotetext{
${ }^{12}$ AG, Pedagang/Muzakki, Wawancara, Marisa 27 Oktober 2019.

${ }^{13}$ MT, PNS/Muzakki, Wawancara, Randangan, 29 Oktober 2019.

${ }^{14}$ KM, Pengusaha/Muzakki, Wawancara, Popayato, 12 Nopember 2019.
} 
menjadi urusan yang bersangkutan dengan Tuhan. Pemerintah, sekali lagi tidak perlu campur tangan dalam pengelolaannya.

Kedua, kecenderungan kontra-optimis. Kecenderungan ini didukung oleh $25 \%$ responden. Nada dasar pemikiran mereka sama dengan kecenderungan pertama, bahwasanya masalah-masalah keagamaan biarlah berjalan seiring dengan kesadaran masyarakat Muslim, tanpa harus pemerintah campur tangan di dalamnya. Bedanya dengan kecenderungan yang pertama, kecenderungan kedua ini masih memberi ruang bagi pemerintah dalam pengelolaan zakat dengan syarat tidak berjalan sendiri. Melibatkan segenap komponen masyarakat lainnya, seperti unsur ulama, tokoh-tokoh agama, tokoh-tokoh adat, tokoh pemuda, dan unsur lain. Sehingga masing-masing pihak dapat saling mengoreksi, sesuai fungsi dan perannya di masyarakat. Jika pengelolaannya didominasi oleh satu unsur saja, misalnya personalianya semua dari kalangan pemerintah, maka dikhawatirkan tidak tercipta pengawasan sebagaimana mestinya. ${ }^{15}$ Karena itu, bagi mereka, peraturan Bupati harus dimaknai sebagai fase awal dan fase transisi, dengan ketentuan bahwa jika dalam implementasinya tidak membawa perubahan dan perbaikan, maka dapat dibatalkan pemberlakuannya. Mereka pada dasarnya sadar bahwa format seperti itu tidak lumrah, tetapi itulah cara yang menurutnya lebih realistis untuk memantau kinerja pengelolaan zakat.

Ketiga, kecenderungan pro-pesimis. Jika peraturan bupati dimaksudkan sebagai upaya untuk melibatkan pemerintah secara langsung dan lebih banyak dalam mengurusi masalah zakat, maka tampak bahwa kecenderungan itu didukung oleh masyarakat Muslim dengan prosentase yang lebih besar. Dari jumlah responden yang ada, 144 di antaranya (atau sekitar 28,8\%) yang menunjukkan kecenderungan pemahaman seperti itu.

Pentingnya keterlibatan pemerintah dalam masalah ini, tampaknya didasari oleh pemahaman bahwa mengurusi masalah zakat juga merupakan bagian dari tugas pemerintah, karena menyangkut kemaslahatan masyarakat. Meskipun demikian, jika dianalisis lebih jauh, maka tampak bahwasanya terdapat benang

${ }^{15}$ MS, PNS/Muzakki, Wawancara, Lemito, 12 Nopember 2019 
merah dari kecenderungan ini, yakni bahwa keterlibatan pemerintah lebih karena pertimbangan strategi, ketimbang beban ideologis yang mutlak.

Menurut HH misalnya, terhadap ajaran-ajaran agama yang mengatur hubungan individu dengan Allah, sebenarnya tidak perlu dukungan dari pemerintah, karena setiap Muslim dapat menegakkannya secara sadar dan sendirisendiri. Tetapi, ajaran agama yang menyangkut hubungan sosial kemasyarakatan seperti zakat, bagaimanapun tetap perlu dukungan dari pemerintah. ${ }^{16}$

Tetapi, meskipun mereka mendukung keterlibatan pemerintah dalam pengelolaan zakat, masalah klasik menyangkut tingkat kepercayaan kembali mengemuka. Bedanya dengan kecenderungan kontra-pesimis yang tingkat kepercayaannya memang sudah di titik nol, kecenderungan ini masih berharap pemerintah mau merubah dan memperbaiki citranya, sehingga lambat laun masyarakat dapat melihat dan merasakan perubahan itu. ${ }^{17}$ Untuk merubah image dan citra itu, kinerja mereka dalam pengelolaan zakat nantinya menjadi taruhannya. Bagaimanapun, mereka yang berada dalam kecenderungan ini, masih berharap pemerintah paling tidak merasa uang zakat yang dikelola adalah milik fakir miskin dan mustahiq lainnya yang tidak pantas jika dikelola tidak semestinya. Perasaan itulah yang diharapkan menjadi semacam "pengawasan melekat" dalam diri pengelola, sehingga betul-betul mengumpulkan dan mendistribusikan zakat secara tepat dan berdaya guna. ${ }^{18}$

Keempat, kecenderungan pro-optimis. 35,7\% atau mayoritas responden memihak pada kecenderungan ini. Nada dasar pemikirannya berada pada spektrum pemahaman yang memandang bahwasanya pengelolaan zakat harus dilakukan dengan penguatan manajemen dan regulasi. Dari sisi manajemen, mereka menyadari betapa besarnya kendala yang dihadapi dalam pengelolaan zakat secara efektif dan berdaya guna, jika tidak didukung oleh lembaga yang kuat dan professional. Bagi mereka, setiap lembaga dapat saja menjadi professional, tetapi aspek "kekuatan" tidak semua lembaga memilikinya. Karena

\footnotetext{
${ }^{16} \mathrm{HH}$, Tokoh Agama/Muzakki, Wawancara, Marisa, 20 Oktobert 2019

${ }^{17}$ MU, Wiraswasta/Muzakki, Wawancara, Marisa 14 Oktober 2019

${ }^{18}$ MB, Kontraktor/Muzakki, Wawancara, Marisa, 19 Oktober 2019
} 
itulah, sepatutnya jika pemerintah dengan jaringan yang dimiliki, terlibat secara langsung dalam lembaga yang mengelola zakat. Keterlibatan pemerintah dalam hal ini, menurut dapat dalam bentuk fasilitator, motivator dan atau bahkan aktor langsung di lapangan. ${ }^{19}$

Aspek kepercayaan (trust) yang selama ini menjadi kendala psikologis bagi banyak kalangan, bagi proponen pendukung kecenderungan ini malah dianggap tidak proforsional jika terlalu dibesar-besarkan. Bagaimanapun kata mereka, sejauh ini di daerah ini belum terbentuk lembaga, karena itu tidak elok rasanya jika lembaga yang akan bergerak untuk kemaslahatan umat itu jauh-jauh hari sudah divonis, dicurigai dan tidak didukung. Bahwa di daerah lain ada kasus, hal itu tidak cukup jadi alasan untuk menumbuhkan pesimisme dan apatisme. ${ }^{20}$ Dalam ungkapan yang agak umum, mereka menyatakan "kenapa harus melihat sisi negatif yang terjadi di daerah lain, boleh jadi itu hanya kasuistik sifatnya. Toh masih banyak contoh positif yang telah ditunjukkan oleh lembaga serupa. Lalu kapan daerah kita akan maju jika hanya sisi negatif yang terus dikedepankan.,"21

Proponen pendukung kecenderungan ini sebenarnya juga tidak sepenuhnya mengetahui bahwa dalam Islam dasar normatif dan fakta empirik memihak kepada kecenderungan yang mereka pahami. Nada dasar pemikiran seperti itu semata-mata mereka kembangkan untuk memberi ruang bagi proses pembangunan daerah ini. Karena itu, bagi mereka, jika dalam proses itu ada hal yang dianggap menyimpang, maka menjadi kewajiban mereka pula nantinya untuk meluruskan. Itulah sebabnya, meskipun menyimpan asa yang tinggi bagi pengelolaan zakat di daerah ini, mereka tetap mewanti-wanti pentingnya pengelolaan dilakukan dengan berpegang teguh pada prinsip-prinsip transparansi dan akuntabilitas. Konteks akuntabel dan transparansi mesti diterapkan dalam pengelolaan zakat, hal itu urgen untuk mengefektifkan fungsi zakat sebagai filantrofi Islam dibidang sosial.

\footnotetext{
${ }^{19}$ NA, Guru/Muzakki, Wawancara, Marisa 22 Oktober 2019

${ }^{20} \mathrm{AB}$, Wiraswasta/Muzakki, Wawancara, Popayato, 15 Nopember 2019

${ }^{21}$ SN, Tani/Muzakki, Wawancara, Randangan, 24 Oktober 2019.
} 


\section{Persepsi dan Relasi Kesadaran Berzakat}

Hasil penelitian menunjukkan bahwa 73,43\% masyarakat yang memiliki penghasilan antara 3,5 juta sampai 4 juta perbulan, sudah merasa sebagai kelompok muzakki. Dari sisi teori, hal itu sudah betul, sebab dengan penghasilan 3,5 juta saja perbulan, maka dalam setahun mereka memiliki penghasilan sebesar 42 juta. Jika dikonversi dengan standar minimal kepemilikan harta yang wajib zakat yakni 85 gram emas, dikali dengan harga emas sekarang 500 ribu pergram, hasilnya adalah 85 gr x 500.000,- = Rp. 42.500.000,- Itu berarti, jika masyarakat yang memiliki penghasilan standar 3 juta merasa wajib zakat, persepsi itu sudah sepantasnya.

Kesadaran zakat masyarakat yang sedemikian tinggi itu, sayangnya tidak linear dengan rutinitas mereka dalam menunaikannya. Ketika mereka ditanyakan rutinitas dalam berzakat, angkanya mengalami penurunan, yakni hanya $64,85 \%$ masyarakat yang rutin mengeluarkan zakat setiap tahun. Angka itu, kembali mengalami penurunan, jika dikaitkan dengan kesadaran menghitung secara rinci keseluruhan harta yang dimiliki. Hasil penelitian menunjukkan hanya $36 \%$ masyarakat yang pernah menghitung secara sadar kepemilikan harta yang dimiliki untuk kepentingan perhitungan jumlah zakat yang harus dikeluarkan.

Sejalan dengan angka itu, terungkap bahwa hanya 34,57\% masyarakat yang mengetahui nishab harta yang harus dikeluarkan zakatnya, selebihnya sebanyak 52,43\% tidak tahu, dan 13\% lainnya tidak menjawab. Tingginya angka responden, yakni $69 \%$ yang nanti mengeluarkan zakatnya jika tiba bulan suci ramadhan.

\begin{tabular}{lccc}
\hline \multicolumn{1}{c}{ Permasalahan } & Ya & Tidak & $\begin{array}{c}\text { Tidak } \\
\text { menjawab }\end{array}$ \\
\hline Penghasilan cukup, merasa wajib zakat & $73,43 \%$ & $9 \%$ & $17,57 \%$ \\
\hline Rutin mengeluarkan zakat & $64,85 \%$ & $33 \%$ & $2,15 \%$ \\
\hline Pernah menghitung harta secara rinci & $36 \%$ & $59,42 \%$ & $4,58 \%$ \\
\hline $\begin{array}{l}\text { Pernah menanyakan ke ulama atau pihak lain } \\
\text { yang dianggap mengetahui }\end{array}$ & $45,71 \%$ & $49,71 \%$ & $4,58 \%$ \\
\hline Mengetahui jenis-jenis harta wajib zakat & $60,57 \%$ & $33,72 \%$ & $5,71 \%$ \\
\hline Mengetahui nishab harta & $34,57 \%$ & $52,43 \%$ & $13 \%$ \\
\hline Menunggu ramadhan & $69 \%$ & $28 \%$ & $3 \%$ \\
\hline
\end{tabular}


Secara sederhana dapat dinyatakan bahwa kesadaran berzakat masyarakat, belum diimbangi dengan pengetahuan yang memadai tentang jenis-jenis harta dan nisabnya yang harus dikeluarkan. Bahkan kesadaran menghitung harta secara keseluruhan masih menunjukkan angka yang kurang menggembirakan. Kesadaran zakat yang terbangun di masyarakat tersebut masih mengikuti pola kultural yang insidentil dan parsial. Belum menjadi kesadaran yang utuh, sebagaimana yang diharapkan oleh agama.

Tingginya angka yang menunjukkan pilihan waktu menunggu ramadhan, semakin menguatkan asumsi tersebut. Menurut DM misalnya, bulan ramadhan adalah bulan yang dijanjikan Allah akan dilipatgandakan pahala jika melakukan kebaikan di dalamnya. Karena itu, sepatutnya jika penunaian zakat juga menunggu datangnya bulan itu. $^{22}$ Pandangan seperti itu, tentu saja tidak seluruhnya salah, tetapi dari sisi manajemen, tentu saja hal itu tidak direkomendasikan, karena akan menyisakan ruang kevakuman bagi pengelola zakat karena zakat hanya bertumpuk pada bulan ramadhan, sementara kebutuhan mustahiq di luar bulan ramadhan juga perlu diantisipasi.

\section{Persepsi Masyarakat Terhadap Perlunya Regulasi Pemerintah Daerah}

Sejarah pengelolaan zakat melalui peraturan pemerintah sebenarnya telah berlangsung lama. Pada zaman Belanda, dulu ada peraturan Bijblad No. 1892 tanggal 4 Agustus 1893 yang mengatur kebijakan zakat. Kebijakan itu dikeluarkan untuk mencegah terjadinya penyelewengan dana zakat untuk digunakan melawan penjajah. Menyadari kebijakan itu tidak efektif, maka dalam kebijakan selanjutnya, melalui Bijblad No. 6200 tanggal 28 Februari 1905, Belanda melarang pegawai pemerintah dan priyayi pribumi untuk membantu kegiatan pengelolaan zakat. ${ }^{23}$

Pasca kemerdekaan, pada tahun 1968, dalam Pidato Isra' Mi’raj tanggal 22 Oktober 1968, Presiden Soeharto menganjurkan untuk menghimpun zakat secara

\footnotetext{
${ }^{22}$ DM, PNS/Muzakki, Wawancara, Marisa, 22 Oktober 2019

${ }^{23}$ Sofyan S. Harahap, "Manajemen Zakat yang Profesional Pasca Undang-Undang Nomor 38 Tahun 1999," dalam Harmoni: Jurnal Multikultural dan Multireligius, Volume VI, Nomor 22, April-Juni 2007, h. 26.
} 
sistematis dan terorganisir. Karena anjuran itulah, maka pada tahun-tahun selanjutnya, berdirilah Bazis di sejumlah daerah, seperti Kalimantan Timur (1972), Sumatera Barat (1973), Jawa Barat (1974), Aceh (1975), Sumatera Selatan (1975), Lampung (1975), Kalimantan Selantan (1977), DKI Jakarta (1982), Sulawesi Utara (1985), Sulawesi Selatan (1985), dan lain-lain. ${ }^{24}$

Pada tahun 1989, dikeluarkan Instruksi Menteri Agama No. 16 tentang Pembinaan Zakat, Infaq dan Shadaqah. Instruksi tersebut menetapkan agar semua jajaran Departemen Agama (Kanwil, Kandepag dan KUA Kecamatan) membantu lembaga-lembaga keagamaan yang mengadakan pengelolaan zakat, infaq dan shadaqah dan agar penggunaaan uang hasil pengelolaannya ditujukan untuk kegiatan pendidikan Islam dan lain-lain.

Pada tahun 1991, dikeluarkan Keputusan Bersama Menteri Dalam Negeri dan Menteri Agama No. 29 dan 47 tentang Pembinaan Amil Zakat Infaq dan Shadaqah. Keputusan Bersama tersebut ditindaklanjuti dengan InstruksiMenteri Agama No. 5 tahun 1991 tentang Pedoman Pembinaan Teknis Badan Amil Zakat, Infaq dan Shadaqah. Di samping itu, terdapat pula Instruksi Menteri Dalam Negeri No. 7 tahun 1998 tentangPembinaan Umum Badan Amil Zakat, Infaq dan Shadaqah.

Untuk menyempurnakan dan meningkatkan pengelolaan zakat, pada tahun 1999 disahkanlah UU No. 38 tentang Pengelolaan Zakat. Undang-Undang tersebut telah diperbarui dengan lahirnya UU No. 23 Tahin 2011. Sebagai tindak lanjut pelaksaaan undang-undang tersebut, telah pula diterbitkan peratiran Presdien No. 14 tahun 2014 tentang Pelaksanaan UU No. 23 Tahun 2011. Sebagai petunjuk teknis, telah dikeluarkan pula Keputusan Menteri Agama No. 118 tahun 2014 tentang pembentukan Baznas Provinsi, jo Keputusan Direktur Jenderal Bimbingan Masyarakat Islam No. DJ.II/568 Tahun 2014 tentang Pembentukam Baznas Kabupaten Kota se-Indonesia. Semua peraturan-peraturan tersebut menunjukkan tingginya perhatian pemerintah terhadap pengelolaan zakat di Indonesia.

\footnotetext{
${ }^{24}$ Djuanda et.al, Pelaporan Zakat Pengurangan Pajak Penghasilan (Jakarta: Rajawali Press, 2006), h. 7.
} 
Konteks Kabupaten Pohuwato, respon masyarakat terhadap keterlibatan pemerintah dalam manajemen zakat cukup menggembirakan. Hasil penelitian menunjukkan bahwa sebanyak $65,7 \%$ responden setuju adanya peraturan pemerintah daerah sebagai payung hukum dalam pengelolaan zakat di daerah ini. Sebagai tindak lanjut, seharusnya segera dilakukan sosialisasi tentang telah diterapkannya Perda Zakat di daerah ini sejak tahun 2008. Tetapi, terhitung 3 tahun sejak ditetapkannya Perda tersebut. Hasil penelitian menunjukkan bahwa sosialisasi itu belum berjalan, sehingga ditemukan fakta bahwa 47,8\% responden bahkan tidak tahu bahwa di daerah ini telah ditetapkan peraturan Bupati tentang hal itu.

Berikut ini ditunjukkan tabel tentang perspesi masyarakat terhadap materi Perda dan sosialisasinya.

\begin{tabular}{lccc}
\multicolumn{1}{c}{ Permasalahan } & Ya & Tidak & $\begin{array}{c}\text { Tidak } \\
\text { Menjawab }\end{array}$ \\
$\begin{array}{l}\text { Mengetahui telah ditetapkannya Perbup } \\
\text { Zakat }\end{array}$ & $30,8 \%$ & $66,8 \%$ & $2,4 \%$ \\
\hline Perlu tidaknya zakat diatur Perbup & $64,8 \%$ & $30 \%$ & $5,2 \%$ \\
\hline Perlu ada sanksi dalam PerbupZakat & $54 \%$ & $42,4 \%$ & $3,6 \%$ \\
\hline Setuju zakat harus disetor ke Baz & $55,6 \%$ & $41,2 \%$ & $3,2 \%$ \\
\hline $\begin{array}{l}\text { Setuju pemotongan gaji langsung 2,5\% } \\
\text { setiap bulan (responden khusus PNS) }\end{array}$ & $63 \%$ & $37 \%$ & $0 \%$ \\
\hline
\end{tabular}

Barangkali yang unik adalah persepsi yang berkembang selama ini bahwa zakat menuntut keikhlasan, sehingga yang tidak ikhlas boleh tidak menunaikannya. Secara normatif, seperti yang telah berulang kali dijelaskan dalam beberapa bagian laporan penelitian ini, tidak ada landasan epistemologi untuk menarik kesimpulan bahwa zakat bersifat sukarela. Sebagai sebuah kewajiban agama yang berdimensi luas, pengelolaannya memang perlu melibatkan kekuasaan. Pemahaman seperti itulah yang menginspirasi Nabi dan sahabat-sahabat besar pada masa-masa awal Islam begitu peduli tentang pengelolaan zakat dengan jalan membentuk amil. Puncaknya, pada masa khalifah Abu Bakar secara terang-terangan beliau mengobarkan perang terhadap pembangkang zakat. 
Di luar perdebatan epistemologi itu, hasil penelitian menunjukkan bahwa 61\% PNS tidak keberatan jika gajinya dipotong untuk alokasi zakat malnya setiap bulan. Seperti halnya kegelisahan-kegelisahan yang terungkap sebelumnya, bagi mereka yang penting pengelolaannya betul-betul dilakukan dengan menjunjung tinggi prinsip-prinsip transparansi dan akuntabilitas. ${ }^{25}$

\section{Persepsi dan Pengetahuan Masyarakat Terhadap Lembaga Pengelola}

Meskipun secara potensial dana umat yang dapat dikumpulkan dari zakat begitu besar, tetapi jika tidak didukung oleh lembaga pengelola yang profesional, maka potensi itu tidak akan tergarap secara maksimal. Karena itu, langkah awal yang mendesak demi terwujudnya tujuan pemberdayaan masyarakat Muslim melalui zakat terutama adalah terbentuknya lembaga pengelola yang independen, transparan, akuntabel dan amanah.

Dalam banyak bagian tulisan ini, telah ditunjukkan bahwa secara normatif maupun historis, Islam secara tegas memposisikan pemerintah sebagai penanggungjawab untuk mempelopori dan mensukseskan pengelolaan zakat. Karena itulah harus ada lembaga amil zakat yang ditugasi pemerintah untuk mengelola, mendistribusikan dan melaporkannya. Memang tidak sepenuhnya alah jika zakat itu diberikan langsung oleh muzakki kepada mustahiq, tetapi dilihat dari segi efektifitas pencapaian tujuan utama zakat, maka dengan cara konvensional tujuan zakat untuk pemberdayaan sulit diwujudkan.

Hasil penelitian menunjukkan bahwa $76 \%$ responden setuju jika dibentuk amil zakat. Responden juga masih menunjukkan tingkat kepercayaan yang menggembirakan, terbukti bahwa $72,8 \%$ responden masih menaruh harapan dan kepercayaan terhadap lembaga yang akan dibentuk nantinya. Tentu saja hal ini merupakan kabar menggembirakan, sebab selama ini justru aspek kepercayaan (trust) menjadi kendala psikologis tersendiri bagi upaya membentuk lembaga amil zakat.

Distribusi persepsi responden terhadap perlunya lembaga dan tingkat kepercayaan dapat dilihat dalam tabel berikut:

\footnotetext{
${ }^{25}$ RA, PNS/Muzakki, Wawancara, Marisa, 16 Oktober 2019.
} 


\begin{tabular}{lcccccc|} 
& \multicolumn{3}{c}{ Frekuensi } & \multicolumn{3}{c|}{ Prosentase (\%) } \\
\cline { 2 - 7 } \multicolumn{1}{c}{ Indikator } & Ya & Tidak & Ragu & Ya & Tidak & Ragu \\
\hline Perlu dibentuk 'amil & 190 & 52 & 8 & 76 & 20,8 & 3,2 \\
\hline $\begin{array}{l}\text { Yakin terhadap 'amil yang } \\
\text { akan dibentuk } \\
\text { (Tingkat kepercayaan) }\end{array}$ & 182 & 40 & 28 & 72,8 & 16 & 11,2 \\
\hline
\end{tabular}

Jika sebelumnya dikemukakan adanya kelompok masyarakat yang cenderung kontra dan pesimis terhadap perlunya zakat dikelola melalui penguatan manajemen dan regulasi melalui perda, mereka itu mewakili $16 \%$ responden yang memang kurang dan atau tidak percaya lagi terhadap lembaga pengelola.

Dikaitkan dengan kepercayaan terhadap lembaga tertentu, hasil penelitian menunjukkan bahwa responden menaruh kepercayaan agak tinggi terhadap lembaga Majelis Ulama Indonesia, kemudian secara berturut-turut Kementerian Agama, Pemerintah Daerah, gabungan berbagai unsur dan terakhir lembaga swasta independen. Untuk mengetahui distribusi tingkat kepercayaan responden terhadap masing-masing lembaga tersebut, dapat dilihat dalam tabel berikut:

\begin{tabular}{lcc}
$\begin{array}{l}\text { Tingkat kepercayaan terhadap instansi } \\
\text { yang akan mengelola zakat }\end{array}$ & Frekuensi & Prosentase (\%) \\
Pemerintah Daerah & 47 & $18,8 \%$ \\
\hline Lembaga swasta independen & 32 & $12,8 \%$ \\
\hline Kementerian Agama & 63 & $25,2 \%$ \\
\hline Majelis Ulama Indonesia & 71 & $28,4 \%$ \\
\hline Gabungan berbagai instansi & 37 & $14,8 \%$ \\
\hline
\end{tabular}

\section{Persepsi dan Pengetahuan Masyarakat Tentang Pola Distribusi}

Meskipun responden menunjukkan dukungan yang besar terhadap dibentuknya lembaga pengelola dan setuju dengan keharusan menyetorkan zakat kepada 'amil, seperti telah disebutkan angka-angkanya sebelumnya, tetapi, $50,28 \%$ responden masih mempraktikkan pola distribusi zakat secara langsung. 
Sangat mungkin hal itu disebabkan karena selama ini memang belum dibentuk lembaga 'amil zakat yang profesional di daerah ini, sehingga pilihan pada pola distribusi langsung menjadi opsi pertama. Tetapi, uniknya, 45,72\% responden mengaku telah mempraktikkan pola distribusi zakat melalui lembaga pengelola yang ada. Itupun karena selama ini yang dikenal sebagai pengelola hanya pegawai syara', maka kepada pegawai syara'lah atau takmir masjid zakatnya disetor. Waktu penyetorannya pun seperti telah disinggung sebelumnya, umumnya masih menunggu bulan ramadhan.

Terhadap pengakuan responden seperti itu, tim peneliti memandang hal itu sebagai mis-perception. Sebab sejauh yang terungkap di lapangan dan berdasarkan pengakuan pegawai-pegawai syara'/takmir masjid, zakat yang disetorkan masyarakat Muslim kepada mereka pada bulan ramadhan itu, sebenarnya hanya zakat fitrah, bukan zakat mal. ${ }^{26}$

Ketika didalami masalahnya, kemudian terungkap bahwa ternyata banyak masyarakat Muslim yang memandang sumbangan yang diberikan kepada pengurus-pengurus mesjid secara insidentil, sudah dianggap sebagai penunaian kewajiban zakat mal mereka. ${ }^{27}$ Padahal, dalam konsep Islam, perlu diingatkan kembali bahwa zakat berbeda dengan infaq, shadaqah, hibah dan semacamnya.

Khusus di kalangan mustahiq, hasil penelitian menunjukkan bahwa $68 \%$ setuju dengan pola distribusi konsumtif. Menurut penuturan KD misalnya, bagi kami golongan ekonomi lemah, pemberian dalam bentuk kebutuhan bahan pokok merupakan jalan keluar yang cepat untuk dapat menyambung hidup secara wajar. ${ }^{28}$ Hal senada diungkapkan oleh AK. Menurutnya, meskipun ada keinginan untuk meningkatkan taraf hidup, tetapi bagi kami yang seperti ini sangat beruntung rasanya jika ada yang memberikan bantuan berupa kebutuhan pokok sehingga dapat ikut merasakan hidup yang layak, meskipun hanya sesaat. ${ }^{29}$

\footnotetext{
${ }^{26}$ NS, Takmir Masjid/Pegawai Syara', Wawancara, Kota Barat, 21 Oktober 2011.

${ }^{27}$ SS, Pedagang/Muzakki, Wawancara, Kota Tengah, 13 Oktober 2011.

${ }^{28}$ KD, Mustahiq, Wawancara, Kota Timur, 25 Oktober 2011.

${ }^{29}$ AK, Mustahiq, Wawancara, Dungingi, 21 Oktober 2011.
} 
Pikiran-pikiran mustahiq seperti itu, tentulah tidak sepenuhnya salah, apalagi diukur dari tingkat kebutuhan mereka terhadap jenis kebutuhan pokok yang selama ini dirasakan kurang memadai. Tetapi, dari sisi pemberdayaan, pikiran-pikiran seperti itu secara bertahap harus direkonstruksi sehingga tumbuh semangat untuk terlibat dalam upaya merubah taraf hidup mereka secara aktif, sehingga nantinya tidak lagi sepenuhnya bergantung pada uluran tangan saudaranya sesame Muslim. Untuk tujuan itu, tentu saja pilihan pada pola distibusi produktif harus diperkenalkan.

Belum lagi ketika responden yang mengaku menerapkan pola distribusi langsung ditanyakan apakah pemberiannya itu disertai dengan saran-saran penggunaan, 91\% menyatakan tidak pernah menyarankan. Berkembang pemahaman di kalangan mereka, bahwa ketika zakat sudah diberikan kepada yang berhak, kewajibannya telah rampung. Soal penggunaan dana zakat yang telah diterima, bagi mereka itu sepenuhnya menjadi urusan penerima, tidak perlu dicampuri. $^{30}$

Hasil penelitian juga menunjukkan bahwa 56\% responden setuju jika nantinya model distribusi produktif yang dijadikan model distribusi 'amil zakat. Sebagian besar responden yang selama ini mempraktikkan pola pemberian langsung konsumtif menyadari tidak efektifnya cara itu dalam rangka pemberdayaan. Sebab umumnya mereka juga mengakui bahwa pola konsumtif langsung itu hanya bersifat sesaat. Tidak menjadi solusi atas ketidakberdayaan mustahiq, khususnya fakir miskin secara ekonomis untuk jangka panjang. ${ }^{31}$

Ketika masalah porsi pembagian ditanyakan kepada responden, hanya 19,2\% yang memandang perlu adanya skala prioritas terhadap kelompok mustahiq yang ada. Selebihnya, 42,4\% berpandangan bahwa dana zakat harus dibagikan kepada semua mustahiq secara merata dan dalam jumlah yang sama, sedangkan 38,4\% lainnya berpandangan bahwa dana zakat harus dibagi merata meskipun bagiannya boleh tidak sama. Tabel berikut dapat menggambarkan hal tersebut secara rinci.

\footnotetext{
${ }^{30}$ RR, Pedagang/Muzakki, Wawancara, Kota Selatan, 16 Nopember 2011.

${ }^{31}$ SQ, PNS/Muzakki, Wawancara, Kota Barat, 20 Nopember 2011.
} 


\begin{tabular}{lcc}
\multicolumn{1}{c}{ Porsi Pembagian Zakat } & Frekuensi & Prosentase (\%) \\
\hline Harus merata dan sama jumlahnya & 106 & $42,4 \%$ \\
\hline Harus merata, boleh tidak sama & 96 & $38,4 \%$ \\
\hline Boleh diprioritaskan & 48 & $19,2 \%$ \\
\hline \multicolumn{1}{c}{ Jumlah } & 250 & $100 \%$ \\
\hline
\end{tabular}

Dengan memperhatikan data-data, dapat disebutkan bahwa kesadaran zakat yang terbangun di masyarakat Muslim Kabupaten Pohuwatomasih insidentil dan parsial, belum menjadi kesadaran yang utuh, sebagaimana yang diharapkan oleh agama.

\section{PENUTUP}

Hasil penelitian menunjukkan bahwamasyarakat Muslim Pohuwatopada dasarnya setuju dengan gagasan pengelolaan zakat. Akan tetapi, terhadap gagasan pengelolaan zakat secara formal melalui Peraturan Bupati, maka mereka terpola dalam beberapa kecenderungan, yakni kecederungan kontra-pesimis, kontra optimis, pro pesimis dan pro optimis. Kesluruhan kecenderungan yang ada tersebut, bermuara pada dua kutub pemikiran yakni menginginkan pengelolaan zakat dilakukan secara kultural dan pandangan yang memihak pada kecenderungan struktural (keterlibatan struktur pemerintah) dalam pengelolaan zakat.

Kecenderungan apapun yang muncul di masyarakat, dibangun berdasarkan persepsi dan pengetahuan mereka diukur dari tingkat kepercayaan mereka terhadap pengelolaan zakat oleh pemerintah. Masyarakat Muslim pada dasarnya setuju dengan gagasan perbut zakat, kendalanya lebih pada soal sosialisasi. Karena itulah, tidak mengherankan jika mayoritas masyarakat mengaku tidak mengetahui bahwa di daerah ini telah diterbitkan Peraturan Bupati tentang Pengelolaan Zakat. 


\section{DAFTAR PUSTAKA}

Djuanda et.al, Pelaporan Zakat Pengurangan Pajak Penghasilan. Jakarta: Rajawali Press, 2006.

Faisal, "Sejarah Pengelolaan Zakat di Dunia Muslim dan Indonesia" dalam Jurnal Analisis Vol. XI, Nomor 2 Desember 2011.

Faisal, Sanafiah. Format-Format Penelitian Sosial: Dasar-Dasar dan Aplikasi, Jakarta: Raja Grafindo Persada, 2007.

Harahap, Sofyan S. "Manajemen Zakat yang Profesional Pasca Undang-Undang Nomor 38 Tahun 1999," dalam Harmoni: Jurnal Multikultural dan Multireligius, Volume VI, Nomor 22, April-Juni 2007.

Ichwan, Muh. Nur. Meretas Kesarjanaan Kritis al-Quran. Jakarta: Teraju, 2003.

Al-Jaziry, Abd al-Rahman. Kitab al-Fiqh ala Madzahib al-Arba'ah, Juz I. Beirut: Dar al-Fikr, 1990.

Maleong, Lexy J. Metodologi Penelitian Kualitatif. Cet. 37; Bandung: Remaja Karya, 2017.

Mar'at. Sikap Manusia, Perubahan dan Pengukurannnya. Jakarta: Ghalia Indonesia, 1981.

Al-Mawardi, Abu al-Hasan. al-Ahkam al-Sulthaniyat wa al-Wilayah al-Diniyat, Beirut: Dar al-Fikr, t.th.

Nasution, Mustafa Edwin. Pengenalan Eksklusif Ekonomi Islam. Jakarta: Kencana, 2006.

Al-Qardhawi, Yusuf. Fiqh Zakat, Dirasah Muqaranah li Ahkamiha wa Falsafatiha fiy Dhau' al-Qur'an wa al-Sunnah. Beirut: Muassasah alRisalah, 1997.

Qudamah, Ibn. al-Mughny al-Muhtaj, Juz II. Riyadh: Maktabah al-Riyadh, 1981.

Sabiq, Sayid. Fiqh Sunnah, Juz I. Beirut: Dar al-Fikr, 1983.

Saleh, Hassan. Kajian Fikih Nabawi dan Fikih Kontemporer. Jakarta: Raja Grafindo Persada, 2008.

Suratmaputra, Ahmad Munif. Filsafat Hukum Islam. Jakarta: Pustaka Firdaus, 2002.

Usman, Iskandar. Istihsan dan Pembaharuan Hukum Islam. Jakarta: Raja Grafindo, 1994.

Walgito, Bimo. Pengantar Psikologi Umum. Yogyakarta: Andi Offset, 2010.

Al-Zuhaily, Wahbah. "Dirasah Muqaranah fi Zakat al-Mal," diterjemahkan oleh Agus Efendi dan Bahruddin Fannany dengan judul "Zakat: Kajian Berbagai Mazhab. Bandung: Remaja Rosdakarya, 2000. 